\title{
Kekerasan Simbolik Dalam Koran Merapi (Analisis Wacana pada Pemberitaan Kekerasan Seksual Perempuan Koran Merapi Edisi Januari-Desember 2014)
}

\author{
Bagus Ajy Waskyto Sugiyanto \\ Program Studi Ilmu Komunikasi, Universitas Widya Mataram \\ bagusajy89@gmail.com
}

\begin{abstract}
Abstrak
Pemberitaan kekerasan seksual pada perempuan dalam Koran Merapi menempatkan posisi laki-laki menjadi subjek sedangkan perempuan menjadi objek, sehingga membentuk posisi yang timpang antara laki-laki dan perempuan. Posisi dominan laki-laki ini yang membuat pemberitaan masih terasa bias gender. Bordieu melihat fenomena ini sebagai kekerasan simbolik, kekerasan yang halus, tak kasat mata. Penelitian ini berupaya untuk melihat bagaiamana wacana kekerasan simbolik dalam pemberitaan kekerasan seksual pada perempuan di Koran Merapi. Untuk mengetahuinya penelitian ini menggunakan metode analisis wacana kritis yang membedah jalinan teks, kognisi, dan sosial pada Koran Merapi. Hasil penelitian menunjukkan bahwa wacana kekerasan simbolik yang terdapat pada pemberitaan Koran Merapi meliputi, objektivikasi seksual pada perempuan, perempuan sebagai penyebab kekerasan seksual, perempuan harus mematuhi kehendak laki-laki, melestarikan mitos "suci" pada perempuan, dan ketidak seriusan dalam memandang esensi kekerasan seksual.
\end{abstract}

Kata Kunci: Koran Merapi, Pemberitaan kekerasan seksual pada Perempuan, Kekerasan Simbolik.

\begin{abstract}
The coverage of sexual violence against women in Koran Merapi places the position of men as subjects while women become objects, thus forming an unequal position between men and women. The dominant position of men is what makes the coverage still feel gender biased. Bordieu sees this phenomenon as symbolic violence, violence that is subtle, invisible. This research seeks to see how the discourse on symbolic violence in the reporting of sexual violence against women in Merapi Newspaper. To find out, this study uses a critical discourse analysis method that dissects the text, cognition, and social fabric of the Merapi newspaper. The results showed that the discourse on symbolic violence contained in the Koran Merapi includes, sexual objectification in women, women as the cause of sexual violence, women must obey the will of men, preserve the myth of "sacred" in women, and not being serious about the essence of sexual violence. .
\end{abstract}

Keywords: Merapi Newspaper, Reporting on sexual violence against women, symbolic violence.

\section{Pendahuluan}

Angka kekerasan pada perempuan di Indonesia semakin meningkat. Bersumber pada Catatan Tahunan Komisi Nasional Anti kekerasan Terhadap Perempuan (CATAHU Komnas Perempuan) 2014, jumlah kekerasan terhadap 
perempuan tahun 2013 mencapai 279.760 kasus, zangka ini meningkat drastis dari tahun 2001 yang hanya berjumlah 3169 kasus. Tampaknya tindakan kekerasan seksual terhadap perempuan ini sudah menjadi budaya, ketika fenomena ini kerap kali terjadi dalam kehidupan bermasyarakat. Subono menjelaskan budaya kekerasan sebagai sesuatu yang seksi dan seksualitas sebagai kekerasan. Budaya memperkosa merupakan serangkaian kepercayaan yang kompleks yang mendukung agresi seksual dan kekerasan pria terhadap wanita (2000: 10).

Budaya kekerasan terhadap perempuan sendiri tampaknya bukanlah barang baru di Indonesia. Kita dapat melihat pada peristiwa kerusuhan 1998, Tim Gabungan Pencari Fakta (TGPF) melaporkan adanya 85 perempuan korban kekerasan seksual yang berlangsung dalam rangkaian kerusuhan Mei 1998, dengan rincian 52 korban perkosaan, 14 korban kekerasan dengan penganiayaan, 10 korban penyerangan/penganiayaan seksual dan 9 orang korban pelecehan seksual (www.komnasperempuan.or.id). TGPF Mei 1998 juga mengidentifikasi bahwa sebagian besar korban kekerasan sesksual berasal dari etnis Tionghoa dan sebagian besar kasus perkosaan adalah gang rape, dimana korban diperkosa oleh sejumlah orang secara bergantian pada waktu yang sama. Kebanyakan kasus perkosaan juga dilakukan di hadapan orang lain. Selain itu TGPF Mei 1998 melaporkan masih adanya ketakutan dari korban untuk melaporkan kekerasan sesksual yang terjadi padanya, hal ini yang mengakibatkan jumlah kasus yang tercatat masih jauh dari akurat. Korban memilih diam karena takut akan pandangan yang diterima dalam masyarakat, adanya stigma-stigma negatif pada korban pemerkosaan justru semakin menguatkan luka pada psikologi korban.

Berita sejatinya tidak hanya merupakan laporan peristiwa, tetapi ada sesuatu yang dapat disiratkan oleh berita. Kadang makna yang tersirat menjadi sesuatu yang penting. Selain itu, berita bisa menjadi sesuatu yang dihiperbolakan. Pemberitaannya tidak menjadi objektif lagi. Dalam dimensi pemberitaan kekerasan seksual pada perempuan, seringkali terdapat bias gender. Kita dapat melihat pada pemilihan judul berita. Judul berita pada kasus kekerasan seksual pada perempuan seringkali menggunakan pilihan kata yang mengumbar sensasi. Tidak hanya itu, judul dibuat dengan kata-kata yang seronok yang dapat menggugah selera untuk dibaca. Dengan menggunakan judul yang sensasional dan juga sejumlah konotasi dan diksi yang dipakai, bertujuan mendramatisir fakta daripada memberikan kelengkapan dan kedalaman fakta. Tetapi yang lebih mengkhawatirkan lagi adalah pengobjektifikasikan perempuan dalam teks.

Muatan teks yang ada cenderung memposisikan perempuan sebagai objek daripada subjek. Dengan muatan berisi kacamata si pelaku (laki-laki), isi teks lebih menjurus pada suatu bentuk pembelaan terhadap pelaku. Perempuan tidak mendapatkan pemberitaan yang proposional. Gambaran perempuan yang ada adalah pihak yang salah, sebagai pihak yang memulai/stimulant, contohnya seperti menyalahkan perempuan yang masih berkeliaran di malam hari. Keterangan "malam hari" secara tidak langsung menjadi akibat dari kekerasan seksual. Menurut Ashandi Siregar hal ini adalah bentuk pemikiran dari surat kabar yang masih 
berkutat pada ide-ide supremasi maskulinitas. Dengan demikian, berita-berita yang dimuat melegitimasikan posisi laki-laki sebagai pihak yang dominan (1999: 446).

Posisi dominan semacam ini, sebetulnya adalah bentuk kekerasan. Oleh Pierre Bourdieu (2001) bentuk kekerasan ini disebut "kekerasan simbolis" atau kekerasan yang tak kasat mata (2001: 32). Kekerasan simbolik menurut Bordieu adalah, pemaksaan dari sistem simbolisme dan makna pada kelompok atau kelas dengan cara tertentu yang kemudian dianggap sah. Kekerasan simbolik memang tersamar seperti yang dikemukakan Mourkabel, bahwa kekerasan simbolik berlawanan dengan kekerasan yang nyata, merupakan kekerasan yang kasat mata, lembut, tidak dikenali, beroprasi melalui kewajiban, loyalitas, keramahan, hadiah, hutang budi, kealiman, atau dengan kata lain melalui semua kebajikan yang dihormati oleh etika kehormatan (2009: 160).

Peneliti memilih Koran Merapi sebagai objek penelitian. Koran Merapi dapat dikategorikan dalam jurnalisme kuning (yellow journalism) atau yang lebih dikenal dengan koran kuning. koran kuning sering menggunakan unsur-unsur sensasional dan dramatisasi dalam pemberitaanya. Selain itu, karakteristik lain adalah penggunaan aspek visual yang dibesar-besarkan, bahkan lebih dominan daripada teks-teks isi berita itu sendiri (Martin Conboy, 2002: 56). Media cetak yang berasal dari Yogyakarta ini terbit pertama kali pada tanggal 1 Maret 2003 dengan oplah antara 3000 hingga 5000 eksemplar. Tanggapan masyarakat yang positif membuat oplah Koran Merapi meningkat sangat pesat. Kunci kesukessan Koran Merapi adalah kejelian dalam mengolah isu yang selama ini jarang disentuh oleh surat kabar lain di Yogyakarta. Isu seperti keriminalitas, dangdut, obat alternatif, ragam hobi, dan supranatural jarang diangkat sebagai tema berita yang diliput tiap hari. Yang membedakan dan membuat peneliti tertarik pada Koran Merapi dengan Koran kuning yang lain adalah pemilihan bahasa yang lebih "santun". Hal ini dapat dilihat pada kepala berita yang masih menggunakan tata bahasa Indonesia standar. Peneliti melihat "kesantunan" bahasa Koran Merapi semakin menyembunyikan praktek-praktek kekerasan simbolik pada perempuan dalam teks berita.

Berdasarkan latar belakang masalah diatas, dapat ditarik rumusan masalah, yakni bagaimana wacana kekerasan simbolik perempuan dalam pemberitaan kekerasan seksual pada Koran Merapi?

\section{Metode}

Artikel ini menggunakan pendekatan kualitatif sebagai landasannya. Kirk dan Miller mendefinisikan penelitian kualitatif sebagai tradisi tertentu dalam ilmu pengetahuan sosial yang secara fundamental bergantung dari pengamatan pada manusia baik dalam kawasannya maupun dalam peristilahannya (2006: 4). Definisi lain menurut Denzin dan Lincoln mengartikan penelitian kualitatif sebagai penelitian yang menggunakan latar ilmiah, dengan maksud menafsirkan fenomena yang terjadi dan dilakukan dengan jalan melibatkan metode yang ada (2004: 1-2 ). 
Metode dalam artikel ini adalah analisis wacana kritis model Van Dijk. Pada analisis wacana kritis model Van Dijk terdapat tiga dimensi yaitu, teks, kognisi sosial dan konteks sosial. Van Dijk menggabungkan ketiga dimensi tersebut kedalam satu kesatuan analisis. Dalam dimensi teks digunakan dalam melihat bagaimana struktur teks dan strategi wacana yang digunakan untuk menegaskan suatu tema tertentu. Pada level kognisi sosial dipelajari proses produksi teks berita yang melibatkan kognisis individu penulis. Sementara pada aspek konteks sosial mempelajari bangunan wacana yang berkembang dalam masyarakat mengenai suatu masalah (Van Dijk, 1993: 249).

\section{Hasil dan Pembahasan}

\section{Analisis Sosial Habitus Perempuan di Indonesia}

Pada masyarakat yang memiliki habitus berbasis pada sistem patriarki secara normatif akan terlihat kedudukan yang timpang antara laki-laki dan perempuan. Hal ini dapat dilihat dari berbedanya pendidikan dalam keluarga terhadap anak perempuan dan laki-laki. Ketika laki-laki diajarkan untuk berani, memimpin, dan aktif, perlakuan terhadap anak perempuan berbeda. Pada masyarakat Indonesia sendiri, sejak kecil sudah dibuat adanya kebebasan terhadap apa yang dilakukan anak laki-laki sedangkan anak perempuan hanya tinggal dirumah (Katjasungkana dkk. 2001: 4-5). Hal ini merupakan proses sosialisasi yang menegaskan bahwa perempuan diposisikan lebih lemah daripada laki-laki. Sejak kecil perempuan sudah dibentuk dengan hanya menjadi tim pendukung, hal ini dikarenakan konstruksi sosial yang menempatkan laki-laki lebih dominan atau sangat kuat. Dalam masyarakat Indonesia sendiri, posisi dominan ada pada lakilaki, contohnya di lingkungan kebudayaan Jawa. Kaum perempuan yang belum sanggup mengembangkan mentalitas kemandiriannya dan untuk keluar dari seluruh rangkaian dominasi yang membelenggunya ternyata perannya masih saja ditentukan sistem kekuasaan feodal aristokratik. Perempuan dianggap sebagai kanca wingking (teman di belakang) dalam kebudayaan masyarakat Jawa yang juga diterapkan dalam berbagai kultur lainnya (Idy Subandy, 1998: 11).

Budaya Jawa sering dianggap tidak mengenal demokrasi. Salah satu sebabnya adalah tradisi kebudayaan Jawa merupakan tradisi kerajaan, tradisi absolutisme. Dalam konteks ini,seharusnya masyarakat Jawa akan sulit menerima kesetaraan antar jenis kelamin. Akan tetapi, sungguh menarik jika kemudian justru ditemukan pola kesetaraan dalam masyarakat Jawa, yang condong menempatkan kedudukan setiap anggota keluarga (suami atau isteri) dalam posisi yang kurang seimbang. Bahkan kedudukan serta peran seorang ibu dianggap penting dalam masyarakat Jawa karena kaum ibu tidak hanya mengasuh dan mendidik anak serta mendampingi suami, tetapi juga diperkenankan untuk keluar rumah melakukan kegiatan ekonomi. Jika peranan wanita dalam ekonomi keluarga jauh lebih berarti dibandingkan suami maka wanita akan mempunyai kekuasaan, pengaruh, kekuatan, posisi tawar yang baik, serta kebebasan yang sama dengan suaminya. Dalam situasi macam itulah, dengan ibu sebagai pusat keluarga, muncul gejala matrifokalitas, yaitu dominasi wanita melalui jaringan yang terjadi di dalam keluarga inti dan antar 
keluarga inti yang terbentuk dan terpelihara oleh wanita; wanita lebih berkuasa dan lebih dominan dalam urusan rumah tangga, sedangkan laki-laki tidak berfungsi (Idy Subandy, 1998: 12-13).

Perempuan yang memiliki posisi tersubordinasi kerap diposisikan sebagai objek seksual, objek pengaturan, dan objek ekspresi kuasa oleh laki-laki. Sebagai contoh, perkosaan adalah manifestasi dari relasi kuasa yang timpang itu. Di dalam konteks ini, karenanya, perkosaan dilakukan tidak sekedar untuk mendapatkan kepuasan seksual. Perkosaan juga dilakukan untuk melukai, mempermalukan, merendahkan, dan menguasai korban (Komnas Perempuan, 2011: 8). Dalam masyarakat patriarki, perempuan dianggap sebagai mahluk yang lemah. Oleh karena itu perkosaan adalah manisfestasi relasi kuasa, maka selama relasi kuasa yang timpang dipertahankan, selama itu pula perkosaan (kekerasan seksual lainnya) bisa dan terus berlangsung.

\section{Kognisi Sosial dalam Produksi Berita}

Dari hasil analisis kognisi sosial melalui teks yang dilakukan terdapat beberapa strategi yang dilakukan wartawan Koran Merapi dalam memproduksi beritanya. Dalam mendapatkan sumber beritanya, wartawan Koran Merapi lebih sering melakukan wawancara dengan pihak polisi yang terkait. Langkah ini membuat pemberitaan lebih terfokus pada kronologis peristiwa yang pada akhirnya mengobjektivikasi korban. Selain itu, pihak kepolisian juga seringkali mengutarakan motif tersangka melakukan kekerasan seksual. Motif-motif tersangka yang didapat dari data adalah, cemburu, minuman beralkohol, nafsu, badan korban, dan korban yang tidak menuruti keinginan tersangka. Motif-motif ini pada akhirnya menjadi alasan pembenaran dari pihak tersangka dalam melakukan aksi kekerasan seksualnya. Dalam pemberitaan Koran Merapi motif/alasan para tersangka ini menempati porsi yang besar, secara tidak langsung Koran Merapi menjadi corong pembelaan diri para tersangka. Parahnya ketika pihak korban bersuara, statement yang dimuat hanya pada perasaan korban atau keluarga korban dan menjelaskan kronologi kejadian.

Wartawan Koran Merapi juga sering terlihat timpang dalam memuat pemberitaan. Seperti yang sudah disebut sebelumnya, bahwa pihak korban tidak menempati porsi berita yang sama dengan sumber yang lain bahkan pihak tersangka. Strategi penghilangan ini sering dilakukan wartawan Koran Merapi dalam menulis pemberitaannya. Selain itu, strategi penghilangan juga dilakukan dengan menghilangkan fakta-fakta yang sifatnya makro, seperti angka kekerasan seksual pada perempuan yang semakin meningkat, lingkungan sosial yang tidak ramah akan kehidupan perempuan, atau kekerasan seksual timbul dari hubungan yang tidak setara antara laki-laki dan perempuan. Akhirnya, pemberitaan Koran Merapi hanya melihat kasus kekerasan seksual pada perempuan sebagai kasus yang terpisah, bukannya dilihat secara tematik.

Cara pandang wartawan Koran Merapi secara case by case ini menunjukkan kegagalan komitmen Koran Merapi dalam mengedukasi pembacanya. Cara ini semakin diperparah dengan strategi generalisasi yang dilakukan wartawan Koran 
Merapi. Pada pemberitaannya sering kali motif tersangka yang marah karena keinginannya tidak dituruti oleh korban muncul. Efeknya pemberitaan semakin menguatkan wacana kepatuhan perempuan kepada laki-laki. Selain itu, motif seperti minuman beralkohol dan nafsu yang memuncak menunjukkan pembelaan tersendiri pada tersangka. Karena akan terlihat bahwa tersangka melakukan kekerasan seksual dengan tidak sadar, atau tidak dengan keinginan sebenarnya. Selanjutnya wartawan Koran Merapi selalu menulis dengan kronologi kejadian yang semakin menyudutkan korban, hal ini semakin menjelaskan bahwa perempuan memang selalu terobjektivikasi.

Pada strategi kontruksi, wartawan Koran Merapi kerap menggambarkan keadaan yang semakin mengobjektivikasi korban. Contohnya seperti barang bukti pada kasus kekerasan seksual, tidak jarang wartawan Koran Merapi menulis dengan jelas barang bukti yang sebenarnya adalah privasi milik korban. Tetapi karena untuk menunjang sensasional berita, barang bukti dimuat untuk semakin menarik minat pembaca. Kronologis kejadian juga dijelaskan dengan detil pada pemberitaan, bagian tubuh korban yang privasi seringkali digunakan untuk mengumbar erotisme. Judul-judul pemberitaan Koran Merapi juga menunjukkan adanya bentuk-bentuk erotisme yang digunakan untuk menarik minat pembaca, tidak heran dalam penulisan judul dibuat dengan huruf yang tebal dan berukuran besar.

Strategi lain yang sering digunakan adalah perubahan urutan. Pada strategi ini wartawan Koran Merapi sebenarnya memiliki pilihan untuk menulis urutan penulisan berita dengan bebas, tetapi yang seringkali digunakan adalah mendahulukan kronologi kejadian kasus kekerasan seksual. Cara ini semakin menunjukkan niat jelas dari Koran Merapi bahwa yang diutamakan adalah bentukbentuk objektivikasi pada perempuan, karena dengan cara itu akan menarik perhatian pembaca. Strategi ini juga semakin menguatkan cara pandang yang bias gender. Alur selanjutnya adalah tanggapan pihak korban, walaupun sebenarnya juga tidak di semua berita terdapat tanggapan pihak korban. Sayangnya tanggapan pihak korban lebih diarahkan pada bagaimana perasaan korban yang sudah jelas terluka dan penjelasan korban tentang kronologi kejadian. Jadi tanggapan korban semakin diarahkan pada pengobjektivikasian diri korban sendiri. Terakhir berita akan ditutup dengan tanggapan pada aspek hukum. Pembicaraan pada aspek hukum hanya berkutat pada pasal dan hukuman apa yang akan dikenakan pada tersangka, sedangkan pandangan pencegahan atau perubahan cara pandang tidak sama sekali ada.

\section{Wacana Kekerasan Simbolik pada Perempuan di Level Teks}

Pertama, adanya objektivikasi seksual pada perempuan. Koran Merapi kerap menggunakan bentuk-bentuk pemberitaan yang bersifat illustrator yang mengutamakan kedalaman aktual suatu peristiwa tersebut. Hal ini secara tidak langsung menyudutkan korban (perempuan). Fakta bahwa korban menjadi korban suatu tindak kekerasan seksual menjadi dangkal ketika pemberitaan hanya mengarahkan pada kronologis peristiwa. Pemilihan-pemilihan judul yang 
menjadikan korban sebagai pihak yang tereksploitasi membuat pembaca diarahkan pada pemberitaan yang erotis.

Kedua, perempuan sebagai penyebab kekerasan seksual. Dalam pemberitaan Koran Merapi, seringkali tersangka (laki-laki) mendapatkan perlakuan khusus. Perlakuan khusus tersebut berwujud pembelan-pembelaan terhadap tersangka melalui detil-detil yang mengarahkan wacana bahwa korban (perempuan) adalah penyebab kekerasan seksual itu terjadi. Hal ini disebabkan, kontrol laki-laki atas otoritas membuat wacana yang beredar selalu berkutat pada perempuan yang menjadi pihak salah. Melihat pada arena hukum kekerasan seksual seringkali dianggap sebagai kejahatan terhadap kesusilaan semata. Menurut komnas perempuan, pandangan ini didukung oleh negara melalui muatan dalam Kitab Undang-Undang Hukum Pidana (KUHP). Dalam KUHP kekerasan seksual seperti perkosaan dianggap sebagai pelanggaran terhadap kesusilaan. Pengkategorian ini tidak saja mengurangi derajat perkosaan yang dilakukan, namun juga menciptakan pandangan bahwa kekerasan seksual adalah persoalan moralitas semata. Inilah yang menyebabkan pembahasan mengenai moralitas berujung pada pertanyaan apakah perempuan masih perawan atau tidak sebelum diperkosa.

Ketiga, perempuan harus mematuhi kehendak laki-laki. Pemilihan bahasa yang digunakan oleh Koran Merapi menunjukkan keharusan perempuan untuk tunduk pada keinginan laki-laki. Contohnya seperti pada kata-kata "puaskan" dan "dilayani" atau dapat dilihat dengan pemilihan Koran Merapi dalam mengutakan detil pemberitaannya bahwa kejadian ini disebabkan oleh pihak perempuan (korban) yang menolak kehendak/keinginan dari laki-laki (tersangka). Klasifikasi nilai dalam konteks sosial tersebut merupakan gejala diskriminasi gender yang memperlakukan wanita sebagai objek penilaian atau sebagai subordinat dari lakilaki. Laki-laki berhak memilih wanita sesuai dengan kepentingan politisnya, melegitimasi status dan perannya sebagai titik ordinat yang menguasai subordinat. Selain itu kedudukan perempuan sebagai pelayan laki-laki juga dipengaruhi oleh perubahan praktik ekonomi. Perempuan mulai didudukkan pada kondisi untuk melayani laki-laki.

Keempat, melestarikan mitos "suci" pada perempuan. Karena masyarakat kita masih memiliki stereotip yang buruk terhadap korban kekerasan seksual. Contohnya seperti wanita nakal, tidak suci, dan sebagainya. Bentuk stereotipstereotip ini semakin menyudutkan korban kekerasan seksual itu sendiri. Karena adanya stereotip-stereotip tersebut, Koran Merapi memiliki strategi untuk menunjukkan dominasi laki-laki atas perempuan secara halus. Strategi tersebut adalah melestarikan stereotip "kesucian" pada perempuan dengan gaya pemberitaan yang mengeksploitasi nilai-nilai pada perempuan. Terlihat abivalen disini, ketika membicarakan hal yang suci (tabu) tetapi diumbar-umbar (populer). Jika dipandang lebih dalam, memang strategi ini digunakan Koran Merapi untuk mempopulerkan hal yang suci dalam ruang beritanya, tetapi terdapat kontrol pelestarian terhadap nilai kesucian pada perempuan pada kognisi perempuan. Tentu ini adalah strategi yang efektif bagi laki-laki dalam menguatkan dominasinya, dengan menguasai pengetahuan akan kelemahan perempuan. 
Kelima, ketidak seriusan dalam memandang esensi kekerasan seksual. Penghalusan bahasa digunakan Koran Merapi dalam pemberitaannya bukanlah bertujuan untuk bersikap "sopan" atau "santun", tetapi untuk mereduksi kejadian yang sebenarnya. Sebagai contoh pemilihan kata seperti: "Dicabuli", "Gara-gara ulah nakalnya", "Digagahi". Pilihan tersebut telah mengalami pereduksian makna yang sebenarnya. Pada artian sebenarnya kata-kata tersebut barafiliasi dengan kekerasan seksual (pemerkosaan), tetapi Koran Merapi lebih memilih menggunakan kata-kata yang lebih "populer" untuk membuat pemberitaan lebih menarik dan nakal saat dibaca oleh masyarakat. Pemilihan grafis pada berita juga menjadi strategi Koran Merapi untuk menarik pembacanya. Hal ini dapat dilihat pada penulisan judul yang menggunakan huruf besar dan tebal yang bertemakan objektivikasi dan sub judul yang menggunakan strategi serupa. Tiap pemberitaan Koran Merapi, selalu menggunakan judul yang sensasional yang dilanjutkan pada detil peristiwa pada sub judulnya, tentu dimaksudkan untuk menjadi fokus yang penting dalam pemberitaan.

\section{Kesimpulan}

Perubahan bentuk media pada Koran Merapi pada tahun 2010 dari koran kuning menuju koran umum pada kenyataanya tidak dapat dikatakan berhasil keluar dari lubang patriarki. Visi Koran Merapi yang ingin mengedukasi pembacanya melalui berita kekerasan seksualnya ternyata masih dibumbui wacana kekerasan simbolik. Perubahan gaya bahasa yang tidak lagi sensasional ala korang kuning menjadi bahasa yang "sopan" saja ternyata tidak cukup. Bahasa "sopan" inilah yang akhirnya merupakan jalan kekerasan simbolik.

Skema wartawan Koran Merapi dalam menulis pemberitaan kekerasan seksual pada perempuan masihlah bias gender. Penulisan berita masih mendahulukan cara pandang yang mengobjektivikasi korban (perempuan). Alasan yang mungkin timbul dari masalah ini adalah "keinginan pasar". Jika ditelisik lebih dalam lagi, keinginan pasar adalah keinginan masyarakat dominan. Dengan kata lain cara pandang masyarakat masihlah bertumpu pada budaya patriarkis. Bahwa skema objektivikasi perempuan atau pembelaan-pembelaan melalui motif tersangka (laki-laki) masihlah dianggap sebagai pembenaran secara mayoritas. Skema inilah yang mengakar kuat pada tiap lapisan masyarakat, begitu pula wartawan.

\section{Referensi}

Aristiarini, Agnes. 1998. Menggagas Jurnalisme Sensitif Gender. Yogyakarta: PMII Komisariat IAIN Sunan Kalijaga

Bograd. 1988. Feminist Perspectiveson Wife Abuse. Newbury Park CA: Sage Publications

Bourdieu, Piere. 2001. Masculine Dominition. California: Standford university press. 
Bourdieu, Piere. 1992. The Logic of Practice, Terj. Richard Nice. Stanford: University. Stanford.

Conboy, Martin. 2002. The Press and Popular Culture. London: Sage Publications Ltd.

Denzin, Norman K. Dan Yvonna S. Lincoln. 2004. Handbook of Qualitative Research. London-thousand Oaks-New Delhi: Sage Publication.

Eriyanto. 2001. Analisis Wacana: Pengantar Analisis Teks Media. Yogyakarta: PT Lkis Pelangi Aksara

Fakih, Mansour. 2001. Menggeser Konsepsi Gender dan Transformasi Sosial. Yogyakarta: Pustaka Pelajar.

Harper, Richard. Cheelen Mahar, dan Charles Wilkes.2009. (Habitus x Modal) + Ranah = Praktik: Pengantar Paling Komprehensif kepada Pemikiran Pierre Bordieu. Yogyakarta: Jalasutra

Haryanto, Sindung. 2012. Spektrum Teori Sosial: Akar Kekerasan dan Diskriminasi. Jakarta: Gramedia Pustaka Utama.

Katjasungkana. N dkk. 2001. Potret Perempuan. Yogyakarta: Pustaka Pelajar.

Komnas Perempuan. 2011. Kekerasan Seksual: Kenali dan Tangan. Jakarta.

Luhulima, Achie Surdiati. 2000. Pemahaman Bentuk-bentuk Tindak KekerasanTerhadap Perempuan dan Alternatif Pemecahannya. Alumni

Moleong, Lexy J. 2006. Metodologi Penelitian Kualitatif. Bandung. PT. Remaja Rosdakarya.

Mourkabel, Nayla. 2009. Sri Lankan Housemaids in Lebanon: Acase of 'Symbolic Violence' and 'Everyday Forms of Resistance'. Amsterdam: Amsterdam University Press.

Sadli, Saparinah. 2010. Berbeda Tapi Setara. Jakarta: Penerbit Buku Kompas.

Siregar, Ashadi (peny.). 1999, Media dan Gender: Perspektif Gender atas Industri Surat Kabar Indonesia. Yogyakarta: LP3Y dan the Ford Foundation.

Siregar, Ashadi (peny.). 1999, Media dan Gender: Perspektif Gender atas Industri Surat Kabar Indonesia. Yogyakarta: LP3Y dan the Ford Foundation.

Subandy, Idi. 1998. Perempuan dan Media,Bandung: Remaja Rosdakarya

Subono, Nur Iman. 2000. Negara dan Kekerasan terhadap Perempuan. Jakarta: Yayasan Jurnal Perempuan Bekerja Sama dengan The Asia Foundation Indonesia.

Tong, R.P. 1998. Feminist Thought: Pengantar Paling Komprehensif kepada Aliran Utama Pemikiran Feminis (terj.). Yogyakarta: Jalasutra.

Thompson, John. B. 2007. Analisis Ideologi: Kritik Wacana Ideologi-ideologi Dunia. Terj. Haqqul yakin. Yogyakarta:IRCiSoD 


\section{Sumber Internet}

http://www.beritasatu.com/hukum/170178-catatan-minus-hiasi-hari-perempuandi-indonesia.html, diakses pada 20-9-2014.

http://www.komnasperempuan.or.id/publikasi/Indonesia/2011/mei/Lembar\%20Fa kta\%20Tragedi\%20Mei\%201998.pdf, dikases pada 20-9-1014

Nani Kurniasih, Kajian Yuridis dan Sosiologis Terhadap Kekerasan yang Berbasis Gender. Diunduh dari http://www.uninus.ac.id/data/data ilmiah/KAJIAN\%20YURIDIS $\% 20 \& \% 2$ 0SOSIOLOGIS\%20KDRT.pdf, 21 April 2015

http://suarapemudajogja.com/2014/12/16/jpy-berani-bicara-itu-istimewa/, akses 11-6- 2016 